\title{
"Identifikasi Perilaku Kerja Karyawan Di Kawasan Industri Yang Berstatus Mahasiswa (Survey Pada Karyawan Industri Kabupaten Karawang Yang Kuliah Di Universitas Buana Perjuangan Karawang)"
}

\author{
Aji Tuhagana \\ Dosen Program Studi Manajemen Universitas Buana Perjuangan Karawang \\ Asep Darojatul Romli \\ Dosen Program Studi Manajemen Universitas Buana Perjuangan Karawang
}

\begin{abstract}
ABSTRAK
Karayawan merupakan bagian terpenting yang akan menggerakkan roda organisasi perusahaan. Perilaku kerja karyawan yang baik akan memberikan dampak kinerja yang baik pula dalam mendukung tujuan perusahaan, dan sebaliknya perilaku kerja karyawan yang tidak baik akan sangat merugikan pencapaian tujuan perusahaan.

Penelitian ini mengidentifikasi 30 indikator kinerja karyawan di perusahaan industry sekitar kawasan industry di Kabupaten Karawang. Sampel adalah mahasiswa yang berprofesi sebagai karyawan di berbagai kawasan indusri. Jumlah sampel sebanyak 230 orang yang diambil secara stratified random sampling dari seluruh mahasiswa yang ada di Universitas Buana Perjuangan.

Hasil penelitian ini menunjukkan bahwa pada umumnya perilaku karyawan industri di Kabupaten Karawang adalah baik, tidak berperilaku "Counterproductive". Perilaku yang harus mendapat perhatian terdapat pada indikator saat karyawan menghadapi kebijakan baru dan menhadapi metode kerja baru. Analisis Faktor membentuk 7 kelompok dengan kemampuan memprediksi mencapai $67,171 \%$ dari populasinya.
\end{abstract}

Key Word : Perilaku Kerja, Perilaku negartif, Perilaku Positif.

\section{A. PENDAHULUAN}

Perkembangan industri dan dunia usaha sejat tahun 200 sampai tahun 2016 di Kabupaten Karawan sangatlah pesat. Hasil Sensus Ekonomi 2016 di Kabupaten Karawang tercatat sebanyak 233.606 unit usaha/perusahaan non pertanian yang dikelompokkan dalam 15 kategori lapangan usaha sesuai dengan Klasifikasi Baku Lapangan Usaha Indonesia (KBLI) 2015, meningkat 5,47 persen dibandingkan dengan hasil Sensus Ekonomi 2006 (SE06) yang berjumlah 221.490 unit usaha/ perusahaan. Bila dibedakan menurut skala usaha, 230.654usaha/perusahaan (98,74 persen) berskala Usaha Mikro Kecil (UMK) dan 2.952 usaha/perusahaan (1,26 persen) berskala Usaha Menengah Besar (UMB). Jumlah usaha/perusahaan menurut lapangan usaha, didominasi oleh lapangan usaha perdagangan besar dan eceran sebanyak 130.317 usaha/perusahaan atau 55,78 persen dari seluruh usaha/perusahaan yang ada di Kabupaten Karawang. 
Keberadaan karyawan sebagai sumber daya manusia sangatlah penting untuk sebuah organisasi bisnis, baik industri mikro, menengah maupun idustri besar. Jumlah tenaga kerja menurut lapangan usaha, sejalan dengan jumlah usaha/perusahaan di Kabupaten Karawang pada tahun 2016 didominasi oleh lapangan usaha perdagangan besar dan eceran sebanyak 214.464 orang tenaga kerja atau 36,23 persen dari tenaga kerja yang ada di Kabupaten Karawang (592.031 Orang). ${ }^{1}$

Sumber daya manusia merupakan individu hidup yang memiliki keunikan tersendiri. Keunikan tersebut merupakan factor bawaan setiap individu. Factor bawaan itu biasa disebut perilaku. Berhasil dan tidaknya tujuan dari organisasi tergantung dari baik dan tidaknya perilaku sumber daya manusia yang dimilikinya. Karakteristik perilaku yang berbeda beda dapat mewarnai dan mempengaruhi perilaku ditempat kerja sebagaiamana diungkapkan oleh Siagian (2006 : 54) mengungkapkan bahwa terdapat beberapa faktor yang mempengaruhi perilaku kerja seseorang seperti faktor genetik yang merupakan sifat-sifat yang dibawa sejak lahir dan merupakan turunan atau bawaan dari kedua orang tuanya seperti kecerdasan, sifat pemarah atau penyabar dan sebagainya.

Selain faktor genetik atau faktor turunan, lingkungan pergaulan yang dihadapi seseorang pada masa hidupnya baik didalam rumah atau lingkungan diluar rumah jugadapat membentuk pola pikir dan kerja seseorang, termasuk lingkungan sekolah dan lingkungan masyarakat yang dijumpai sehari-hari.

Dalam kehidupan seseorang faktor pendidikan juga memiliki pengaruh penting karena didalam pendidikan ada usaha secara sadar dan sistematis dalam rangka mengalihkan pengetahuan dari seorang kepada orang lain (Siagian, 2006 :54). Pendidikan dapat bersifat formal seperti pendidikan dalam sekolah, bangku kuliah atau lembaga pendidikan lainnya dan juga non-formal seperti pendidikan yang di berikan orang tua terhadap anaknya atau atasan kepada bawahannya.

Notoatmodjo (2003) mendefiniskan perilaku adalah tindakan atau aktivitas dari manusia itu sendiri yang mempunyai bentangan yang sangat luas antara lain : berjalan, berbicara, menangis, tertawa, bekerja, kuliah, menulis, membaca, dan sebagainya. Dari uraian ini dapat disimpulkan bahwa yang dimaksud perilaku manusia adalah semua kegiatan atau aktivitas manusia, baik yang diamati langsung, maupun yang tidak dapat diamati oleh pihak luar. Kemudia Prawirosentono (1999:35), mendefiniskan perilaku adalah suatu karakteristik

\footnotetext{
${ }^{1}$ https://karawangkab.bps.go.id/pressrelease/2017/10/11/114/hasil-pendaftaran--listing--usaha-perusahaansensus-ekonomi-2016-di-kabupaten-karawang.html
} 
penting dari pribadi untuk melakukan kegiatan". Perilaku merupakan hasil gabungan dari berbagai faktor psikologis. Faktor-faktor psikologis tersebut merupakan hasil kombinasi dari faktor fisik, biologis, dan kondisi sosial yang mempengaruhi lingkungan kehidupan seseorang.

Siagian, (2006 :54) yang menyatakan bahwa faktor-faktor pembentuk perilaku seorang karyawan (1) Faktor Genetik, adalah sifat-sifat yang dibawa sejak lahir yang bahkan merupakan "warisan" dari kedua orangtuanya. Misalkan tentang latarbelakang kehidupan karyawan, seperti kecerdasan, sifat pemarah, penyabar dan lain-lain (2) Faktor Lingkungan, adalah situasi dan kondisi yang dihadapi seseorang pada masa muda di dalam rumah dan dalam lingkungan yang lebih luas, termasuk lingkungan sekolah dan lingkungan masyarakat dekat yang dijumpai sehari-hari; (3) Faktor Pendidikan, adalah usaha secara sadar dan sistematis dalam rangka mengalihkanpengetahuan dari seorang kepada orang lain. Pendidikan dapat bersifat formal dan juga non-formal, dan (4) Faktor Pengalaman, yakni pengalaman seseorang sejak kecil turut membentuk perilaku dalam kehidupan organisasionalnya. Pengalaman dapat membentuk sifat apatis, keras kepala, tidak toleran, mudah putus asa, dan sebagainya.

Colquit, et all (2009 : 37) mengemukakan empat dimensi perilaku kerja karyawan, yakni (1) Task performance, (2) citizenship behaviour, dan (3) counterproducrive behaviour. Task performance dan citizenship behaviour merupakan dua dimensi yang memberikan kotribusi positif terhadap organisasi, sedangkan counterproductivebehaviour memberikan kontribusi negative bagi organisasi. Task Performance, meliputi aspek rutinitas kerja dan adaptasi kerja terutama terhadap hal-hal baru. Citizenship behaviour, meliputi aspek (1) interpersonal (perilaku saling membantu, sopan santun dan sportifitas, (2) aspek organisasi (perilaku berpendapat, kebajikan dan gotong royong). Counterproductive behaviour, meliputi aspek (1) property deviance terhadap perngrusakan kekayaan perusahaan dan pencurian, (2) Production Deviance, meliputi aspek penurunan semangat dan penyalahgunaan produktivitas, (3) political Deviance, meliputi aspek pergunjingan dan ketidaksopanan, (4) personal Aggression, meliputi aspek pelecehan dan penyalahgunaan wewenang.

Irmin (2004 : 44) berpendapat bahwa perilaku positif pada diri seorang karyawan terdiri dari (1) Penampilkan etos kerja yang tinggi, (2) Menunjukkan hubungan personal yang simpatik; (3) Mampu manyikapi perubahan secara positif; (4) Memiliki kendali diri yang kuat, (5) Mampu meringankan tugas atasan; (6) Mampu menjadi contoh orang lain; (7) Mampu mebedakan Antara yang hak dan kewajiban; (8) Kreatif dan inovatif; dan (9) Berjiwa besar dan berlapang dada seperti menghargai keberadaan orang lain, mengakui kelebihan orang lain, 
mampu Manahan hawa nafsu, tidak suka mencela orang lain, tidak mudah kecewa, bersikap baik pada orang lain yang memusuhi kita dan selalu berfikir positif.

Gary S Topchik (2001 : 95) menjelaskaan empat belas tipe dari perilaku negative seseorang karyawan di tempat kerja, yaitu (1) Tipe Locomotif, mengekspresikan sikap negatifnya dengan cara melindas orang lain, (2) Tipe Perfeksionis; (3) Tipe Manusia Es (penolak); (4) Tipe "Bukan Tugas Saya"; (5) Tipe Penyebar Gosip; (6) Tipe Pesimis; (7) Tipe Miskin Komitmen; (8) Tipe Pengkritik; (9) Tipe Tukang Ngenbek; (10) Tipe Rela Berkorban; (11) Tipe Menyalahkan Diri Sendiri; (12) Tipe Pencari Kambing Hitam; (13) Tipe Mudah Retak; dan (14) Tipe Manusia Detail

\section{B. METODOLOGI}

Tujuan penelitian ini adalah untuk mengidentifikasi Perilaku Kerja Karyawan di Kawasan Industri di Kabupaten Karawang. Populasi dalam penelitian ini adalah Seluruh Mahasiswa Universitas Buana Perjuangan Karawang yang berstatus sebagai karyawan pada perusahaan yang tersebar di seluruh Kawasan Industri Kabupaten Karawang. Jumlah anggota populasi ada sebanyak 542 orang mahasiswa. Jumlah sampel dihitung menggunakan rumus slovin (dalam Sugiyono 2008 : 78) pada tingkat kesalahan $5 \%$, sehingga ditemukan jumlah sampel sebanyak sebanyak 230 .

$$
\mathrm{n}=\mathrm{N} /\left(1+\mathrm{Ne}^{2}\right)=542 /\left(1+542 \times \mathbf{0 , 0 5} \mathbf{5}^{2}\right)=230 \text { orang. }
$$

Teknik sampling menggunakan stratified sampling dengan memilah berdasarkan jenis kelamin, sehingga ditemukan jumlah sampel laki-laki sebanyak 99 dan perempuan sebanyak 131 orang, yang selanjutnya dilakukan penyebaran kuesioner kepada mahasiswa yang bersedia untuk ikut dalam penelitian ini.

Untuk menjelaskan perilaku kerja karyawan maka dilakukan dengan Analisis deskriptif dan analisis factor. Analisis deskriptif dugunakan untuk menjelaskan perilaku kerja karyawan secara umum dan membandingkannya pada tingkat industrinya, sedangkan analisis faktor digunakan untuk mencari faktor-faktor yang mampu menjelaskan hubungan atau korelasi antara berbagai indikator independen yang diobservasi. 


\section{HASIL PENELITIAN DAN DISKUSI}

Hasil penelitian menjelaskan 30 perilaku kerja karyawan di Kabupaten Karawang sebagaimana ditampilkan pada tabel 1 di bawah ini.

Tabel 1

Deskripsi perilaku Kerja Karyawan industri di Kabupaten Karawang

\begin{tabular}{|l|l|c|l|}
\hline No & \multicolumn{1}{|c|}{ Perilaku Kerja Karyawan Industri } & Skor & \multicolumn{1}{|c|}{ Keterangan } \\
\hline 1 & Menghadapi Rutinitas Kerjanya & 891 & Baik \\
\hline 2 & Sikap dalam melaksanakan tugas rutinnya & 871 & Baik \\
\hline 3 & Menghadapi Kebijakan Baru & 770 & Cukup Baik \\
\hline 4 & Menghadapi Metode Kerja Baru & 788 & Cukup Baik \\
\hline 5 & Menghadapi pimpinan Baru & 840 & Baik \\
\hline 6 & Perilaku Membantu Teman Kerja & 951 & Baik \\
\hline 7 & Kinerja Membantu Teman Kerja & 875 & Baik \\
\hline 8 & Perilaku Sopan Santun & 942 & Baik \\
\hline 9 & Kesopanan Dalam Bekerja & 940 & Baik \\
\hline 10 & Sportivitas Dalam Bekerja & 892 & Baik \\
\hline 11 & Sportivitas Dalam Berinterkasi & 889 & Baik \\
\hline 12 & Perilaku Dalam Berpendapat & 808 & Baik \\
\hline 13 & Perilaku Dalam Sikap Berorganisasi & 810 & Baik \\
\hline 14 & Perilaku Baik Dalam Bekerja & 892 & Baik \\
\hline 15 & Tenggangrasa Dalam Bekerja & 840 & Baik \\
\hline 16 & Perilaku Gotong Royong & 901 & Baik \\
\hline 17 & Kinerja Dalam Kelompok & 854 & Baik \\
\hline 18 & Memelihara Kekayaan Perusahaan & 931 & Baik \\
\hline 19 & Tidak merusak Kekayaan Perusahaan & 797 & Baik \\
\hline 20 & Tidak menggelapkan Kekayaan Perusaan & 1007 & Sangat Baik \\
\hline 21 & Tidak terlibat Korupsi & 1029 & Sangat Baik \\
\hline 22 & Tidak melemahkan Semangat Kerja & 956 & Baik \\
\hline 23 & Semangat Kerja & 882 & Baik \\
\hline 24 & Tidak menyalahgunakan kerja & 943 & Baik \\
\hline 25 & Tidak menyalahgunakan Peralatan & 926 & Baik \\
\hline 26 & Tidak melakukan sensasi negatip & 994 & Sangat Baik \\
\hline 27 & Sopan dalam Bekerja & 1017 & Sangat Baik \\
\hline 28 & Tidak Pelecehan Gender & 9010 & Sangat Baik \\
\hline 29 & Tidak pelecehan Kerja & & Sangat Baik \\
\hline 30 & Tidak penyalahgunaan wewenang & & \\
\hline- & Modus (yang paling banyak muncul) & \\
\hline & & 997 & \\
\hline
\end{tabular}


Keterangan : Rentang Skala

\begin{tabular}{r|r|r|r|r|}
230 & 598 & 792 & 966 & 1150 \\
\hline Tidak Baik & Kurang Baik & Cukup Baik & Baik & Sangat Baik
\end{tabular}

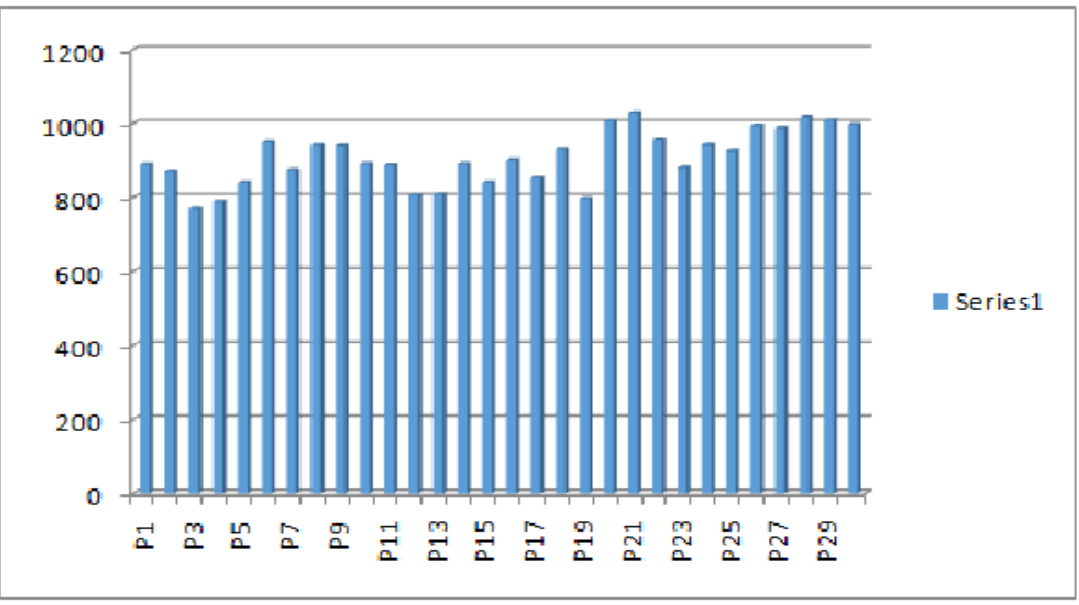

Data di atas menjelaskan bahwa secara umum perilaku kerja karyawan industri di Kabupaten Karawang adalah baik. Indikator yang sangat baik meliputi aspek tidak menggelapkan kekayaan perusahaan, tidak melakukan korupsi, tidak melakukan sensasi negative, sopan dalam bekerja, tidak melakukan pelecehan gender dan pelecehan kerja. Sedangkan perilaku yang harus mendapat perhatian adala pada indicator saat karyawan menghadapi kebijakan baru dan menghadapi metode kerja baru.

Analisis $K M O$ dan Barlett's Test untuk menguji tingkat kesahihan pengujian dari seluruh indicator yang di uji. Hal ini dapat di lihat pada table $K M O$ and Bartlett's Test di jelaskan pada tabel 2 di bawah ini.

Tabel 2

\section{KMO and Bartlett's Test}

\begin{tabular}{|c|c|c|}
\hline $\begin{array}{l}\text { Kaiser-Meyer-Oll } \\
\text { Adequacy. } \\
\text { Bartlett's Test of } \\
\text { Sphericity }\end{array}$ & $\begin{array}{l}\text { asure of Sampling } \\
\text { Approx. Chi-Square } \\
\text { Df } \\
\text { Sig. }\end{array}$ & $\begin{array}{r}4.050 \mathrm{E} 3 \\
435 \\
.000\end{array}$ \\
\hline
\end{tabular}


Hasil analisis menujukkan nilai KMO 0,868 dan Sign 0.00. Nilai ini lebih besar dari 0,5 yang berarti hasil analisis sangat baik dan sangat signifikan (nyata) untuk memprediksi hasil analisis yang diukur.

Analisis anti image menunjukan Semua indicator tidak ada yang di-reduct, artinya semua indicator mendukung penuh terhadap hasil analisis factor yang diuji. Analisis Total Variance Explain menjelaskan jumlah factor yang dibentuk dari hasil penelitian ini. Hasil penelitian menunjukkan bahwa analisis akan membentuk 7 kelompok dengan kemampuan memprediksi mencapai $67,171 \%$ dari populasinya. Hal ini dapat dilihat pada table Hal ini dapat dilihat pada table 3 di bawah ini :

Tabel 3

Total Variance Explained

\begin{tabular}{|c|c|c|c|c|c|c|}
\hline \multirow[b]{2}{*}{ component } & \multicolumn{3}{|c|}{ Initial Eigenvalues } & \multicolumn{3}{|c|}{ Extraction Sums of Squared Loadings } \\
\hline & Total & $\%$ of Variance & Cumulative $\%$ & Total & $\%$ of Variance & Cumulative $\%$ \\
\hline 1 & 7.787 & 25.956 & 25.956 & 7.787 & 25.956 & 25.956 \\
\hline 2 & 5.877 & 19.590 & 45.546 & 5.877 & 19.590 & 45.546 \\
\hline 3 & 1.640 & 5.467 & 51.012 & 1.640 & 5.467 & 51.012 \\
\hline 4 & 1.497 & 4.990 & 56.002 & 1.497 & 4.990 & 56.002 \\
\hline 5 & 1.243 & 4.144 & 60.147 & 1.243 & 4.144 & 60.147 \\
\hline 6 & 1.062 & 3.541 & 63.687 & 1.062 & 3.541 & 63.687 \\
\hline 7 & 1.045 & 3.484 & 67.171 & 1.045 & 3.484 & 67.171 \\
\hline 8 & .891 & 2.971 & 70.142 & & & \\
\hline 9 & .828 & 2.761 & 72.903 & & & \\
\hline 10 & .797 & 2.656 & 75.559 & & & \\
\hline 11 & .726 & 2.420 & 77.979 & & & \\
\hline 12 & .694 & 2.312 & 80.291 & & & \\
\hline 13 & .626 & 2.088 & 82.379 & & & \\
\hline 14 & .583 & 1.943 & 84.322 & & & \\
\hline 15 & .551 & 1.836 & 86.158 & & & \\
\hline 16 & .520 & 1.734 & 87.892 & & & \\
\hline 17 & .435 & 1.449 & 89.341 & & & \\
\hline 18 & .414 & 1.379 & 90.719 & & & \\
\hline 19 & .347 & 1.158 & 91.877 & & & \\
\hline 20 & .337 & 1.124 & 93.002 & & & \\
\hline 21 & .329 & 1.098 & 94.100 & & & \\
\hline 22 & .295 & .983 & 95.082 & & & \\
\hline 23 & .266 & .888 & 95.970 & & & \\
\hline 24 & .247 & .823 & 96.793 & & & \\
\hline 25 & .223 & .745 & 97.538 & & & \\
\hline 26 & .197 & .656 & 98.194 & & & \\
\hline 27 & .175 & .583 & 98.777 & & & \\
\hline 28 & .154 & .512 & 99.289 & & & \\
\hline 29 & .111 & .372 & 99.661 & & & \\
\hline 30 & .102 & .339 & 100.000 & & & \\
\hline
\end{tabular}

Extraction Method: Principal Component Analysis.

Analisis kompenen factor Setelah dilakukan rotasi sebanyak 10 kali dijelaskan pada tabel 4 di bawah ini: 
Table 4

\begin{tabular}{|c|c|c|c|c|c|c|c|}
\hline \multicolumn{8}{|c|}{ Rotated Component Matrix ${ }^{s}$} \\
\hline & \multicolumn{7}{|c|}{ Component } \\
\hline & 1 & 2 & 3 & 4 & 5 & 6 & 7 \\
\hline Tidak terlibat Korupsi & .855 & -.016 & .144 & -.034 & -.079 & -.125 & .031 \\
\hline Tidak menyalahgunakan kerja & .855 & .003 & .026 & .101 & -.063 & -.128 & .122 \\
\hline Tidak menyalahgunakan Peralatan & .837 & .067 & .132 & .043 & .001 & -.035 & .065 \\
\hline Tidak pelecehan Kerja & .837 & .016 & -.002 & -.036 & .176 & .254 & -.042 \\
\hline $\begin{array}{l}\text { Tidak menggelapkan Kekayaan } \\
\text { Perusaan }\end{array}$ & .834 & .002 & .066 & .010 & -.051 & -.084 & .077 \\
\hline Tidak melakukan sensasi negatip & .827 & .021 & .005 & .069 & .046 & .089 & -.052 \\
\hline Tidak Pelecehan Gender & .825 & .042 & .003 & -.036 & .216 & .273 & -.014 \\
\hline Tidak melemahkan Semangat Kerja & .809 & .056 & .080 & -.050 & -.175 & -.073 & -.153 \\
\hline Tidak penyalahgunaan wewenang & .795 & -.021 & -.051 & .078 & .124 & .008 & .025 \\
\hline Sopan dalam Bekerja & .788 & .140 & -.045 & .023 & .134 & .194 & -.073 \\
\hline Memelihara Kekayaan Perusahaan & .644 & -.074 & .038 & .050 & -.075 & -.295 & -.077 \\
\hline Sportivitas Dalam Berinterkasi & .021 & .779 & .023 & -.015 & .236 & -.192 & .004 \\
\hline Perilaku Gotong Royong & .095 & .752 & .072 & .134 & -.011 & .187 & .153 \\
\hline Sportivitas Dalam Bekerja & .013 & .705 & .199 & -.003 & .364 & -.170 & .083 \\
\hline Kinerja Dalam Kelompok & .052 & .652 & .272 & .199 & .018 & .096 & -.163 \\
\hline Tenggangrasa Dalam Bekerja & .050 & .627 & -.007 & .057 & .098 & .322 & .212 \\
\hline Perilaku Dalam Berpendapat & -.112 & .553 & .237 & -.003 & .125 & .380 & .082 \\
\hline Perilaku Baik Dalam Bekerja & .051 & .518 & .392 & .204 & .153 & .327 & -.013 \\
\hline Tidak merusak Kekayaan Perusahaan & .015 & .495 & .168 & .283 & -.238 & .139 & -.300 \\
\hline Sikap Menghadapi Rutinitas Kerja & .073 & .137 & .797 & .042 & .117 & .051 & .003 \\
\hline Kinerja Tugas Rurtin & .154 & .121 & .793 & .047 & .135 & .078 & .071 \\
\hline Semangat Kerja & .035 & .197 & .491 & .305 & .108 & -.017 & -.023 \\
\hline Kinerja Membantu Teman Kerja & -.088 & .341 & .472 & .187 & .194 & -.012 & .346 \\
\hline Menghadapi Metode Kerja Baru & .047 & .124 & .169 & .755 & .097 & .241 & .012 \\
\hline Menghadapi pimpinan Baru & .036 & .117 & -.035 & .747 & .157 & -.285 & .215 \\
\hline Menghadapi Kebijakan Baru & .068 & .135 & .286 & .668 & .057 & .296 & -.131 \\
\hline Kesopanan Dalam Bekerja & .086 & .197 & .264 & .143 & .807 & .084 & .094 \\
\hline Perilaku Sopan Santun & .040 & .312 & .261 & .195 & .778 & .051 & .005 \\
\hline Perilaku Dalam Sikap Berorganisasi & .005 & .341 & .100 & .232 & .038 & .612 & .083 \\
\hline Perilaku Membantu Teman Kerja & -.009 & .113 & .093 & .051 & .042 & .088 & .893 \\
\hline
\end{tabular}

Dari hasil analisis ini dapat dijelakan bahwa perilaku kerja karyawan industry di Kawasan Industri Kabupaten Karawang terbagi atas 7 kategori, sebagai berikut :

1. Kategori 1 berperan dalam membangun perilaku baik dalam bekerja sebesar 25,96 \%, terdiri dari indicator : Tidak terlibat korupsi; tidak menyalahgunakan kerja; tidak menyalahgunakan peralatan; tidak melakaukan pelecehan kerja; tidak menggelapkan kekayaan perusahaan; tidak melakukan sensasi negative; tidak melakukan pelecehan gender; tidak melemahkan semanagat kerja; tidak menyalahgunakan wewenang; sopan dalam bekerja;dan memelihara kekayaan perusahaan

2. Kategori 2 berperan dalam membangun perilaku baik dalam bekerja sebesar 19,59\% terdiri dari indicator : Sportifitas dalam berinteraksi, berperilaku baik dalam bergotong royong; sportifitas dalam bekerja, kinerja dalam kelompok; tenggangrasa dalam bekerja; 
perilaku dalam berpendapat; berperilaku baik dalam bekerja dan tidak merusak kekayaan perusahaan.

3. Kategori 3 sebesar 5,467\% berperan dalam membangun perilaku baik dalam bekerja terdiri dari indicator :Sikap menghadapi rutinitas kerja; kinerja tugas rutin; semangat kerja da kinerja membantu teman kerja.

4. Kategori 4 berperan dalam membangun perilaku baik dalam bekerja sebesar $4,990 \%$ terdiri dari indicator :Menghadapi metode kerja baru; menghadapi pimpinan baru; mengadapi kebijakan baru;

5. Kategori 5 berperan dalam membangun perilaku baik dalam bekerja sebesar $4,144 \%$ terdiri dari indicator :Kesopanan dalam bekerja dan perilaku sopan santun

6. Kategori 6 berperan dalam membangun perilaku baik dalam bekerja sebesar 3,541\% terdiri dari indicator : perilaku dalam sikap berorganisasi

7. Kategori 7 berperan dalam membangun perilaku baik dalam bekerja sebesar $3,484 \%$ terdiri dari indicator : Perialu membantu teman kerja

\section{E. KESIMPULAN}

Hasil penelitian ini menunjukkan bahwa secara keseluruhan, perilaku karyawan industri di Kabupaten Karawang menunjukkan perilaku yang baik. Itu artinya bahwa para karyawan yang berstatus sebagai mahasiswa memiliki perilaku yang baik dalam hal tidak berperilaku kerja "Counterproductive". Indikator yang sangat baik meliputi aspek tidak menggelapkan kekayaan perusahaan, tidak melakukan korupsi, tidak melakukan sensasi negative, sopan dalam bekerja, tidak melakukan pelecehan gender dan pelecehan kerja. Sedangkan perilaku yang harus mendapat perhatian terdapat pada indikator saat karyawan menghadapi kebijakan baru dan menhadapi metode kerja baru. 


\section{DAFTAR PUSTAKA}

Biro Pusat Statistika Kabupaten Karawang. https://karawangkab.bps.go.id /pressrelease /2017/10/11/114/hasil-pendaftaran--listing--usaha-perusahaan-sensus-ekonomi2016-di-kabupaten-karawang.html

Colquitt, Jason A, Jeffery A. Lepine, Michael J. Wesson, Organizational Behaviour : Improving Performance And Commitment In The Workplace, Published by McGraw-Hill/Irwin. New York, NY, 10020. 2009.

Gary S Topchik, Managing Workplace Negativity. Amacom. Unites States. 2001

Irmin, Soejitno dan Abdul Rochim, Membangun Disiplin Diri Melalui Kecerdasan Spiritual dan Emosional. Batavia Pers. Yogyakarta. 2004

Notoatmodjo, Soekidjo. Pendidikan dan Perilaku Kesehatan. Rineka Cipta. Jakarta. 2003 Prawirosentono S, Manajemen Sumber Daya Manusia, Kebijakan Kinerja Karyawan. BPFE. Yogyakarta. 1999.

Siagian Sondang. P, Organisasi, Kepemimpinan dan Perilaku Organisasi. PT. Gunung Agung. Jakarta. 2006 